\title{
Masks Reduce Viral Inoculum of SARS-CoV2
}

J Gen Intern Med 36(4):1124-5

DOI: $10.1007 /$ s11606-020-06406-9

(C) Society of General Internal Medicine 2021
We think that viral inoculum may be one of the factors contributing to this dysregulated immune response but agree with the author that co-morbidities and other factors in the host (including age) play important roles in disease outcomes. Therefore, we agree with the author that facial masking, along with other important COVID-19 mitigation public health strategies, such as social distancing, testing in nursing homes and good infection control, and hand hygiene, are all important. Our commentary was focused on a single factor that could contribute to disease severity that had not been raised much in the literature, but the excellent work done to date to define other risk factors is acknowledged and appreciated.

Thank you again for the opportunity to respond to the important points raised in this letter-M. Gandhi, C. Beyrer, E. Goosby

Monica Gandhi, $M D, M P H^{1}$

Chris Beyrer, $M D, M^{2} H^{2}$

Eric Goosby, $M D^{1}$

${ }^{1}$ Department of Medicine, Division of HIV, Infectious Diseases and Global Medicine, University of California, San Francisco (UCSF),

San Francisco, CA, USA

${ }^{2}$ Departments of Medicine and Public Health, Johns Hopkins Bloomberg School of Public Health, Baltimore, MD, USA

Corresponding Author: Monica Gandhi, MD, MPH; Department of Medicine, Division of HIV, Infectious Diseases and Global Medicine, University of California, San Francisco (UCSF), San Francisco, CA, USA (e-mail: Monica.Gandhi@ucsf.edu).

\section{Compliance with Ethical Standards:}

Conflicts of Interest: The authors declare that they have no conflict of interest.

\section{REFERENCES}

1. Guallar MP, Meiriño R, Donat-Vargas C, Corral O, Jouvé N, Soriano V. Inoculum at the time of SARS-CoV-2 exposure and risk of disease severity. Int J Infect Dis 2020;97:290-292. https://doi.org/10.1016/j.jjid.2020.06. 035

2. Little $\mathbf{P}$ et al. Reducing risks from coronavirus transmission in the home-the role of viral load. BMJ 2020;369:m1728. https://doi.org/10. 1136/bmj.m1728

Published online January 22, 2021 
3. Ryan KA. Dose-dependent response to infection with SARS-CoV-2 in the ferret model: evidence of protection to re-challenge. bioRxiv 2020.05.29.123810. https://doi.org/10.1101/2020.05.29.12381

4. Van Damme W, Dahake R, van de Pas R, Vanham G, Assefa Y. COVID 19: Does the infectious inoculum dose-response relationship contribute to understanding heterogeneity in disease severity and transmission dynamics? Medical Hypotheses 2020; 110431. https://doi.org/10.1016/j.mehy. 2020.110431.

5. Karimzadeh S, Bhopal R, Nguyen Tien H. Review of infective dose, routes of transmission, and outcome of COVID-19 caused by the SARS-CoV-2 virus: comparison with other respiratory viruses. Preprints 2020 2020070613
6. Bielecki M, Züst R, Siegrist D, Meyerhofer D, Gerardo Crameri GA, Stanga Z, Stettbacher A, Buehrer TW, Deuel JW. Social Distancing Alters the Clinical Course of COVID-19 in Young Adults: A Comparative Cohort Study. Clinical Infectious Diseases 2020

7. Rouse BT, Sehrawat S. Immunity and immunopathology to viruses: what decides the outcome? Nat Rev Immunol 2010;10(7):514-526

Publisher's Note: Springer Nature remains neutral with regard to jurisdictional claims in published maps and institutional affiliations. 